\title{
Profil Pemimpin Publik: Studi Deskriptif mengenai Kepemimpinan pada Generasi Milenial
}

\author{
Anissa Lestari Kadiyono ${ }^{1}$, Gianti Gunawan ${ }^{2}$ \\ ${ }^{1}$ Fakultas Psikologi, Universitas Padjadjaran, Sumedang, Indonesia \\ ${ }^{2}$ Universitas Kristen Maranatha, Bandung, Indonesia \\ e-mail: anissa.lestari@unpad.ac.id
}

\begin{abstract}
The objective of this research is to describe the type of Indonesian leader expected by millennials based on the exploration of task, relationship, and change orientation. Millennials are currently reaching $30 \%$ of the Indonesian population. Their voices can determine what kind of leaders that are expected to lead Indonesia. This research is a quantitative method with a survey technique. The sampling method conducted using convenience sampling and there are 275 respondents who are millennial beginner voters, consisting of students from 26 universities spread across Indonesia. The results show that the value that should be in the leader according to millennials is leaders who showed the real work, responsible, and decisive person. The change orientation shows a higher domination compared to the orientation of the task orientation and relationship orientation.
\end{abstract}

Keywords: leadership, leader value orientation, millennial generation

\begin{abstract}
Abstrak
Tujuan penelitian ini untuk menelaah tipe pemimpin yang diharapkan oleh generasi milenial untuk dapat memimpin bangsa Indonesia berbasis eksplorasi orientasi tugas, relasi, dan perubahan. Generasi milenial merupakan generasi yang saat ini persentasenya mencapai $30 \%$ dari penduduk Indonesia. Oleh karenanya, suara mereka sangat menentukan pemimpin seperti apa yang diharapkan dapat memimpin Indonesia. Penelitian ini merupakan penelitian kuantitatif dengan teknik survei. Teknik pengambilan sampel yang dipakai adalah convenience sampling dan terdapat 275 responden generasi milenial yang merupakan pemilih pemula, yang terdiri atas mahasiswa dari 26 universitas yang tersebar di Indonesia. Hasil penelitian menunjukkan bahwa nilai yang seharusnya ada pada pemimpin menurut generasi milenial adalah sosok pemimpin yang memiliki kerja nyata, bertanggung jawab, dan tegas. Orientasi akan nilai perubahan (change orientation) memiliki dominasi yang lebih tinggi dibandingkan dengan orientasi nilai tugas (task orientation) maupun relasional (relationship orientation).
\end{abstract}

Kata Kunci: kepemimpinan, orientasi nilai pemimpin, generasi milenial

\section{Pendahuluan}

Pemimpin merupakan hal penting, yang akan mengarahkan pada pencapaian tujuan yang diharapkan. Pemimpin dengan sosok tertentu akan menjadi sumber inspirasi dan penentu untuk dapat mewujudkan Indonesia yang maju, makmur, dan sejahtera. Banyak konsep kepemimpinan dikemukakan untuk dapat mewujudkan Indonesia menjadi bangsa yang besar, namun hal ini memiliki banyak aplikasi dan tentu saja penerapan yang berbeda. Dalam Northouse (2013), seorang leader berperan dalam membantu anggotanya mencapai tujuan kelompok atau organisasi. Dalam Robbins (2002), pemimpin yang dikatakan efektif adalah yang mampu membantu anggotanya sampai ke pencapaian tujuan mereka, dan mengurangi hambatan yang dihadapinya.

Dilihat dari komposisi kependudukan Indonesia saat ini, yang terdiri atas 265 juta jiwa (Badan Pusat Statistik, 2019). Sebanyak $30.94 \%$ diantaranya adalah penduduk yang tergolong generasi milenial (Badan Pusat Statistik, 2019). Generasi 
milenial adalah penduduk yang terlahir mulai tahun 1980 hingga 2000 atau lazim disebut dengan Generasi Y. Definisi dari generasi ialah sekelompok individu yang mengidentifikasikan kelompoknya berdasarkan kesamaan tahun lahir, atau umur, atau lokasi, atau kejadian-kejadian yang terjadi dalam kehidupannya. Teori tentang perbedaan generasi dipopulerkan oleh Neil Howe dan William Strauss (1991, dalam Jones \& Hosein, 2010). Menurut Howe dan Strauss (1991， 2000, dalam Jones \& Hosein, 2010), generasi dibagi berdasarkan kesamaan rentang waktu kelahiran dan kesamaan kejadian historis. Pembagian generasi tersebut juga banyak dikemukakan oleh peneliti lain dengan label yang berbeda-beda, tapi maknanya sama (Simões \& Gouveia, 2008). Menurut Howe dan Strauss (2000, dalam Jones \& Hosein, 2010), yang disebut dengan generasi milenial ialah penduduk yang kelahirannya mulai dari tahun 1982 sampai dengan tahun 2000. Kategori penduduk ini merupakan jumlah dominan dalam penduduk produktif saat ini.

Berdasarkan kajian Kowske dkk. (2010), generasi milenial adalah generasi yang sangat menghargai perbedaan. Dalam memecahkan persoalan, generasi ini juga tergolong pragmatis. Selain yang disebutkan sebelumnya, dari sisi karakteristik personalnya, generasi ini memiliki rasa optimisme yang tinggi, fokus pada prestasi, percaya pada diri sendiri dan nilai-nilai moral serta sosial (Burke dkk., 2015). Pola komunikasi yang dilakukan juga terbuka dengan menggunakan sosial media, memiliki keterbukaan pandangan politik dan ekonomi serta terpapar teknologi secara umum (Myers, 2014).

Kajian teori dan penelitian empirik tentang kepemimpinan diawali dengan pendekatan sifat, dilanjutkan dengan pendekatan perilaku, dan terakhir berkembang pendekatan keefektifan pemimpin (Derue \& Humphrey, 2011). Kajian-kajian tersebut sangat diperlukan untuk mencari cara-cara baru memimpin dalam kondisi dan situasi saat ini. Karena gaya kepemimpinan yang tepat pada masa lalu belum tentu relevan diterapkan pada masa sekarang (Sun dkk., 2016). Derue dan Humphrey (2011) mengungkapkan konsep kepemimpinan efektif secara umum yang dapat digambarkan pada gambar 1 .

Konsep kepemimpinan efektif pada gambar 1 yang secara lebih spesifik membahas mengenai leader behavior yang dibahas dalam penelitian ini, menggambarkan bahwa dalam menjalankan fungsi sebagai pemimpin, terdapat perilaku kepemimpinan yang mengarahkan pemimpin untuk dapat menunjukkan efektivitasnya. Hal ini adalah orientasi terhadap tugas (task-oriented), orientasi terhadap hubungan (relational-oriented), orientasi terhadap perubahan (change-oriented) dan passive leadership, yaitu kepemimpinan berdasarkan penunjukkan manajemen atau yang tidak menunjukkan perilaku apa-apa.

Orientasi tugas adalah pelaksanaan kinerja pemimpin dengan menentukan standar pengerjaan tugas dan memastikan anggota kelompok untuk melakukan kinerja sesuai dengan standar kinerja tugas tersebut. Pemimpin memberikan harapan dan standar kinerja sehingga dapat menimbulkan komitmen, motivasi kerja, dan melakukan tindakan korektif untuk mengarahkan anggota dalam berperilaku sesuai dengan tuntutan tugas.

Selanjutnya orientasi relasi adalah pertimbangan terhadap aspek hubungan antar manusia dalam organisasi yang meliputi pertimbangan akan rasa menghormati dan fokus pada kesejahteraan kelompok. Perilaku yang ditampilkan berupa partisipasi aktif dalam kelompok, mengembangkan anggota kelompok dan memberdayakan anggota kelompok secara aktif. Pendekatannya lebih ditekankan pada upaya pencapaian kesejahteraan kelompok secara bersama. Orientasi terhadap perubahan adalah upaya untuk melakukan transformasi atau perubahan secara mendasar terhadap kelompok. 


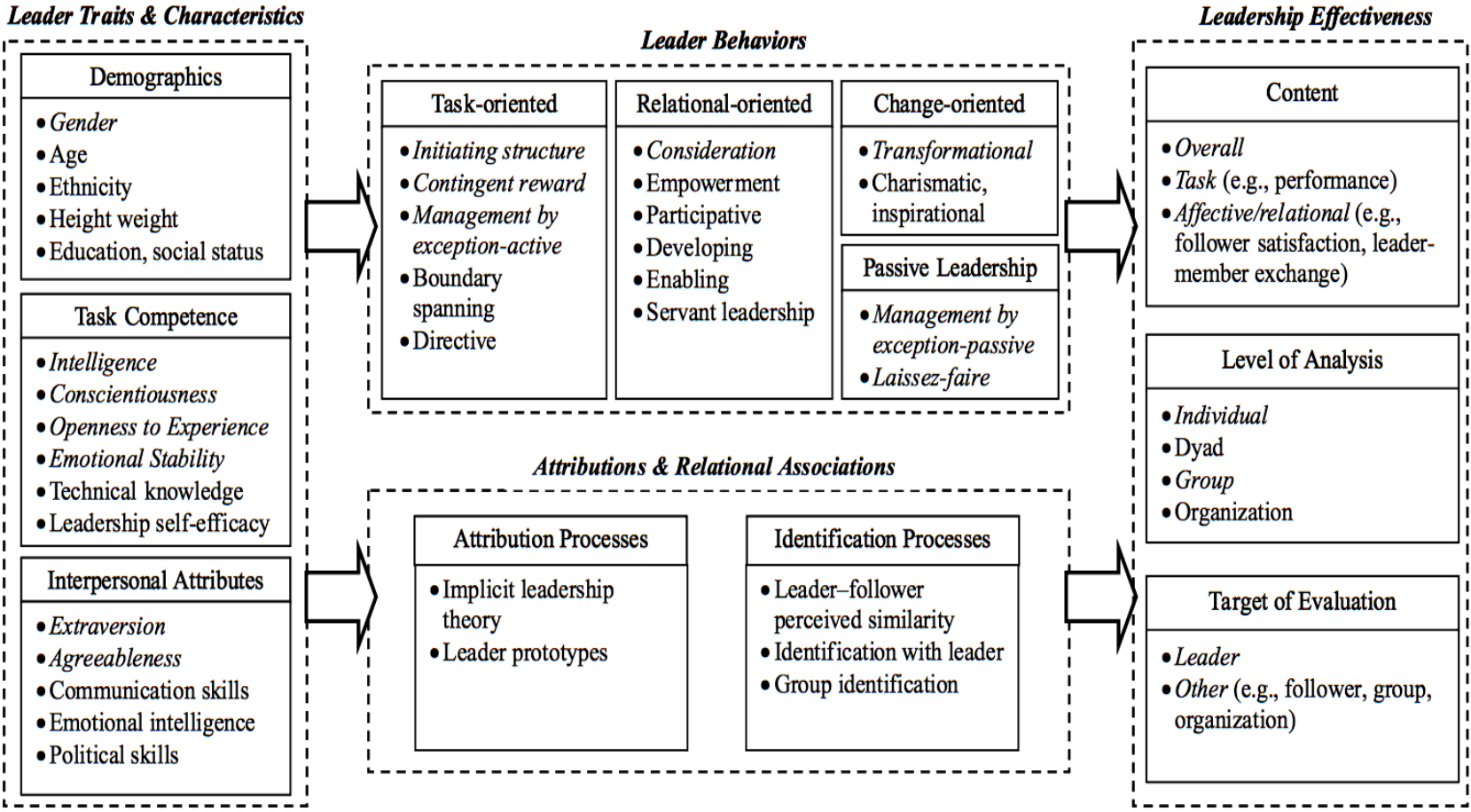

Gambar 1. Konsep kepemimpinan efektif (Derue \& Humphrey, 2011)

Pemimpin adalah seorang yang inspirasional dan karismatik. Pemimpin memiliki kewibawaan untuk mengarahkan kelompok untuk melakukan perubahan dari kondisi yang saat ini telah ada. Sedangkan kepemimpinan secara pasif adalah pemimpin yang mendapatkan mandat untuk memimpin dari manajemen namun tidak menampilkan perilaku kepemimpinan dan tidak melakukan perilaku kepemimpinan secara khusus.

Mahasiswa diharapkan mengerti akan situasi bangsa dan negara serta memperbanyak pengetahuannya dalam berbagai bidang. Mereka juga diharapkan mampu berpikiran kritis dan lebih berani dalam menyatakan fakta serta realita yang ada, serta memiliki wawasan yang luas dalam mengatasi suatu masalah yang berdampak pada bangsa dan negara. (Fauziah, 2015). Generasi milenial merupakan generasi yang saat ini persentasenya mencapai $30 \%$ dari penduduk Indonesia. Oleh karenanya, suara mereka sangat menentukan pemimpin seperti apa yang diharapkan dapat memimpin Indonesia. Perilaku pemimpin yang efektif memiliki orientasi tertentu yang diharapkan dapat memimpin generasi milenial yang saat ini adalah generasi yang cukup mendominasi tenaga kerja produktif untuk membawa bangsa ke arah kemajuan dan kesejahteraan. Disamping itu, belum ada penelitian ilmiah mengenai pemimpin yang ideal menurut generasi milenial di Indonesia. Berdasarkan pemikiran ini, maka penelitian ini ditujukan untuk mendapatkan model kepemimpinan ideal bagi generasi milenial sehingga didapatkan arah orientasi yang diharapkan untuk dapat memimpin bangsa Indonesia.

\section{Metode Penelitian}

Metode penelitian yang digunakan adalah kuantitatif dengan teknik survei. Teknik pengambilan sampel yang digunakan adalah convenience sampling, yaitu pengambilan sampel didasarkan pada ketersediaan elemen dan kemudahan untuk mendapatkannya.

Partisipan penelitian sebanyak 275 mahasiswa yang merupakan generasi milenial pemilih mula, berasal dari 26 
universitas yang tersebar di Indonesia, yang terdiri dari 82 mahasiswa (29.82\%) dan 193 mahasiswi $(70.18 \%)$ dengan rentang usia 20-27 tahun.

Persepsi akan pemimpin ideal bagi generasi milenial diukur menggunakan pertanyaan terbuka dan bersifat umum, yaitu: "Apa saja harapan anda terhadap pemimpin di Indonesia?”. Bentuk pertanyaan terbuka ini kemudian diklasifikasi berdasarkan pengelompokkan jawaban responden.

Leadership Questionnaire (Derue \& Humphrey, 2011) yang terdiri 16 item digunakan untuk mengukur bagaimana harapan responden terhadap profil pemimpin publik yang dilihat dari orientasi tugas (contoh item: "Mengharuskan setiap pegawai untuk biasa menyelesaikan pekerjaan sesuai dengan standar yang ditentukan"), orientasi hubungan (contoh item: "Berusaha untuk selalu mendekatkan diri, melakukan kunjungan langsung ke seluruh elemen masyarakat"), dan orientasi perubahan (contoh item: "Maтpu menularkan antusiasme perubahan kepada masyarakat"). Respon subjek menggunakan 4 pilihan respon, yaitu: 1 (tidak perlu) sampai dengan 4 (selalu). Pada penelitian ini, alat ukur memiliki koefisien reliabilitas sebesar .842.

\section{Hasil Penelitian dan Pembahasan}

Berdasarkan data yang didapatkan, hasil penelitian menunjukkan bahwa generasi milenial memiliki preferensi pemimpin dapat dilihat pada gambar 2 mengenai kriteria pemimpin. Selanjutnya, dapat dilihat pada gambar 3 mengenai kriteria pemimpin yang diharapkan.

Generasi milenial memiliki persepsi bahwa pemimpin yang diharapkan memiliki wujud kerja nyata, memiliki tanggung jawab, tegas, anti korupsi, berpendidikan, dan mengayomi masyarakat. Kerja nyata adalah adanya produk pembangunan yang nyata, adanya perubahan mewujudkan Indonesia yang lebih baik, membangun perekonomian, melakukan pemerataan pembangunan, dan menjadi lebih baik dari sebelumnya. Hal ini lebih menyentuh generasi milenial yang lebih menekankan pada adanya pencapaian dalam bentuk prestasi. Data dalam bentuk kemajuan, pemerataan pembangunan, dan kebaikan akan memberikan penguatan pada pilihan pemimpin bagi generasi milenial yang memiliki perhatian khusus dalam bentuk-bentuk prestasi. Tanggung jawab menjadi profil kedua yang diharapkan dari generasi milenial memberikan penekanan pada profil pemimpin yang dapat memegang amanah yang diberikan oleh rakyat. Hal ini berupa pemenuhan janji untuk melayani masyarakat dan bekerja secara bersungguh-sungguh. Profil ini memberikan dampak bahwa pembahasan atas apa yang telah dilakukan pemimpin bila dibandingkan dengan janji pada saat kampanye merupakan hal yang penting yang menunjukkan keterbukaan dan pemenuhan kewajiban.

Profil tegas menggambarkan karakter personal yang diharapkan dapat cepat tanggap dan mampu meregulasi masalah. Pemimpin juga diharapkan dapat memberikan teladan pada masyarakat dan memberikan dampak positif pada upaya mewujudkan Indonesia yang lebih baik. Profil lain yang juga dinilai penting pada generasi milenial adalah karakter personal berupa anti korupsi, berpen-didikan, dan mengayomi masyarakat. Anti korupsi dijabarkan dengan memberantas kemiskian dan mengedepankan kepentingan rakyat, serta adanya upaya untuk menyejahterakan masyarakat. Sedangkan berpendidikan menunjukkan kemampuan untuk berpikir kreatif, pintar, dan maju. Hal ini juga menunjukkan kemampuan untuk melakkan inovasi, dan memaksimalkan sumber daya yang dimiliki dalam mencapai kemajuan. Mengayomi masyarakat merupakan profil pemimpin yang memperhatikan masyarakat dalam membuat kebijakan, mampu menyejahterakan rakyat dan menjalankan undang-undang serta melindungi hak-hak dasar warga negara. 


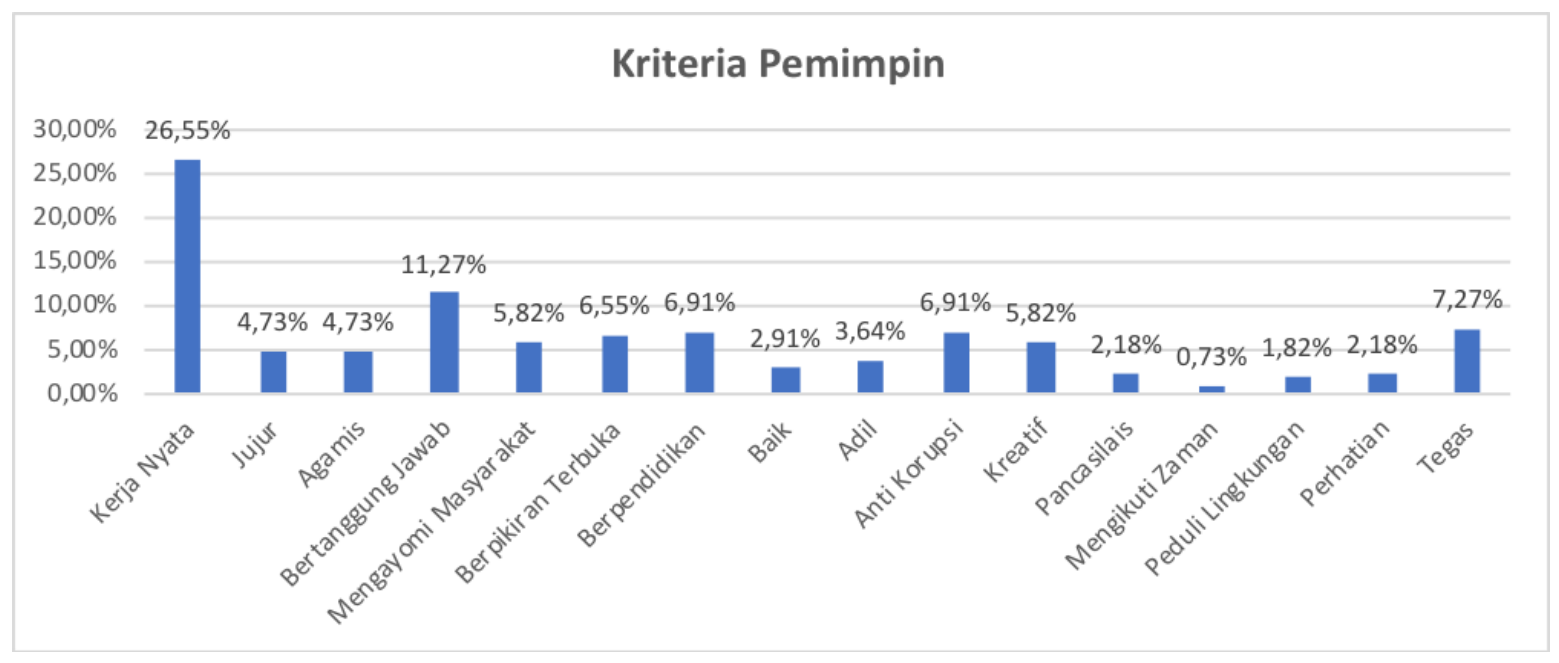

Gambar 2. Kriteria pemimpin

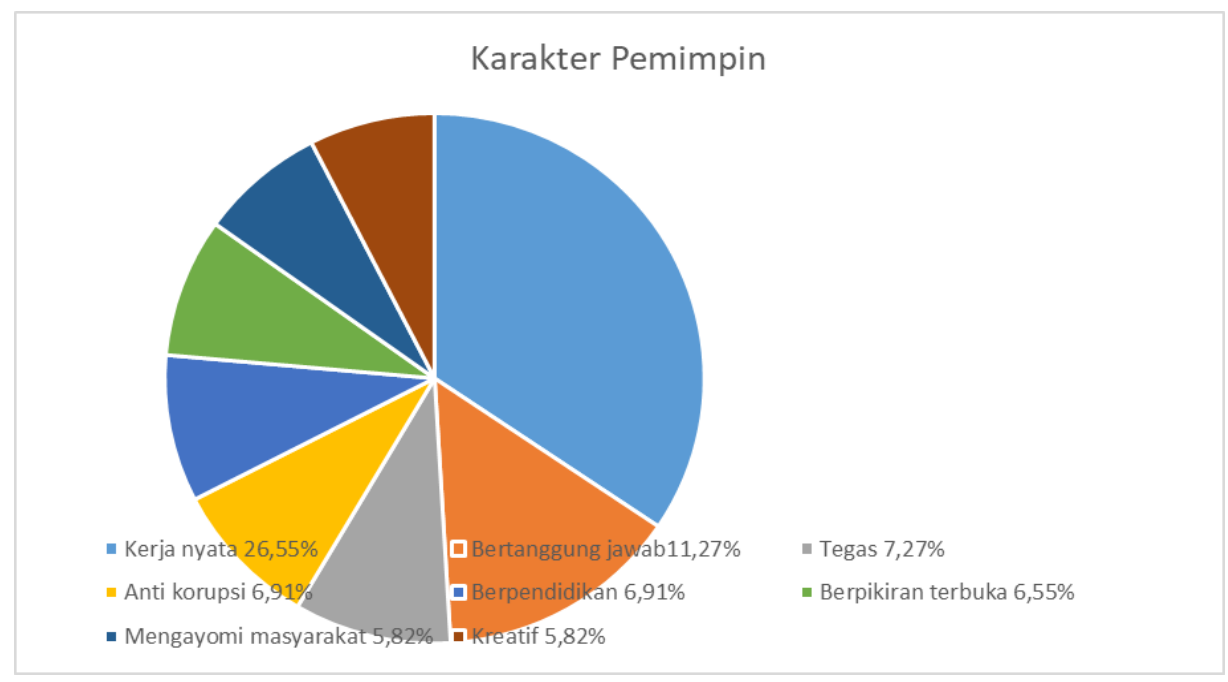

Gambar 3. Karakter pemimpin

Dengan menelaah kepemimpinan efektif berdasarkan konsep yang dikemukakan oleh Derue dan Humphrey (2011) maka orientasi akan perubahan merupakan hal yang dominan. Sebanyak $34.7 \%$ menganggap change orientation merupakan orientasi yang paling penting dimiliki pemimpin publik. Sebanyak $34.4 \%$ responden menganggap rational orientation adalah orientasi yang penting dimiliki oleh pemimpin publik, dan sisanya $33.5 \%$ menganggap task orientation yang penting dimiliki pemimpin publik. Hal ini dapat dilihat dalam studi deskriptif berdasarkan rerata nilai dalam gambar 4 mengenai orientasi kepemimpinan publik.
Berdasarkan kajian rerata orientasi kepemimpinan publik, didapatkan bahwa change orientation atau orientasi terhadap perubahan merupakan orientasi utama yang seharusnya ada pada pemimpin (3.41). Hal ini mendominasi orientasi kepemimpinan publik yang terdapat pada sosok pemimpin. Orientasi perubahan merupakan perilaku pemimpin yang berorientasi pada kemampuan untuk memfasilitasi dan mendorong adanya perubahan dalam kelompok. Menurut Yukl (2009), perilaku pemimpin yang berorientasi pada perubahan mencakup tindakan seperti mengembangkan dan mengomunikasikan visi untuk perubahan, mendorong pemikiran inovatif, dan pengambilan risiko. 
Distribusi Rerata Orientasi Kepemimpinan Publik

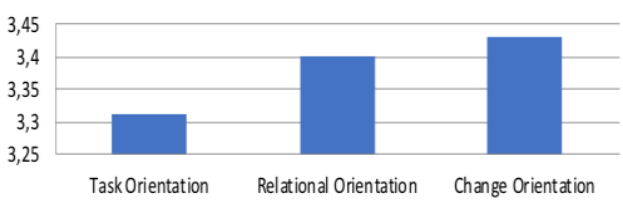

Gambar 4. Orientasi kepemimpinan public

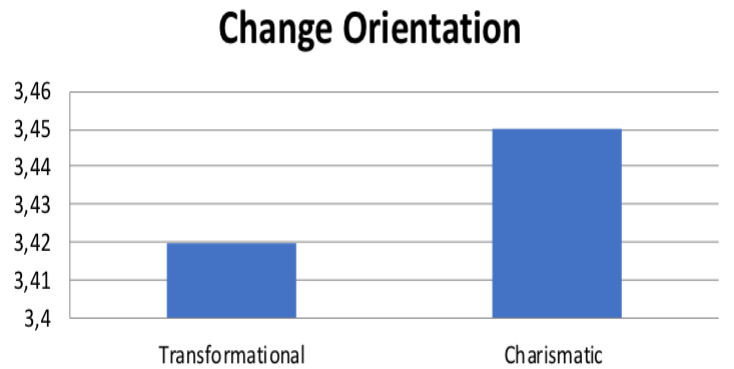

Gambar 5. Change orientation

Bila ditelaah lebih jauh, orientasi perubahan yang dimaksud oleh responden dapat dipetakan dalam gambar 5. Orientasi perubahan yang diperlukan dalam profil pemimpin publik oleh generasi milenial adalah pemimpin yang karismatik. Karisma ialah suatu keadaan yang biasanya dikaitkan dengan kemampuan leader dalam membangun rasa kagum dari masyarakat kepada dirinya. Atribut ini biasanya terlihat dari gaya bicara, berjalan, atau tindakan. Perilaku pemimpin dipersepsi memiliki dasar pertimbangan dari sisi pelaksanaan tugas dan hubungan dengan anggota kelompoknya atau masyarakat (Halpin \& Winer, 1957; Fleishman, 1967, dalam Mujtaba dkk., 2010).

Komposisi orientasi relasi yang dimiliki oleh profil pemimpin publik dapat digambarkan pada gambar 6. Orientasi relasi yang diharapkan dimiliki oleh pemimpin bagi generasi milenial terdapat pada adanya pertimbangan dalam pengambilan keputusan dan pemberdayaan masyarakat dalam keputusan maupun perilaku yang ditampilkannya. Orientasi pemimpin dari sisi relasi menunjukkan bahwa pemimpin perlu memiliki perhatian lebih pada nilai, kebutuhan, motivasi, dan potensi-potensi yang dimiliki oleh anggota (Hammal, 2006). Kebijakan yang diambil memiliki dasar-dasar pertimbangan bagi kesejahteraan masyarakat dan memiliki fokus perhatian pada upaya pemberdayaan diri. Hal ini memberikan gambaran akan aspek penting yang seharusnya ada pada profil pemimpin bagi generasi milenial.

Kepemimpinan bagi generasi milenial di Indonesia memperhatikan aspek hubungan, bagaimana pemimpin mengakomodasi minat anggota kelompok/ masyarakat dan mengambil keputusan berdasarkan upaya pencapaian tujuan masyarakat menjadi lebih sejahtera, seperti halnya kepemimpinan berbasis budaya komunal yang memiliki aspek relasi lebih kuat (Mujtaba \& Isomura, 2012). Pemimpin diharapkan memfasilitasi masyarakat sesuai dengan kebutuhan masyarakat untuk dapat mengeksplorasi potensi atau keunggulan mereka dan pada akhirnya ikut berperan serta dalam membangun wilayah.

\section{Relational Orientation}

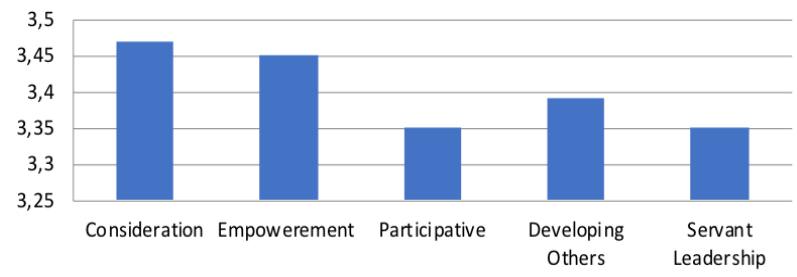

Gambar 6. Relational orientation

Task Orientation

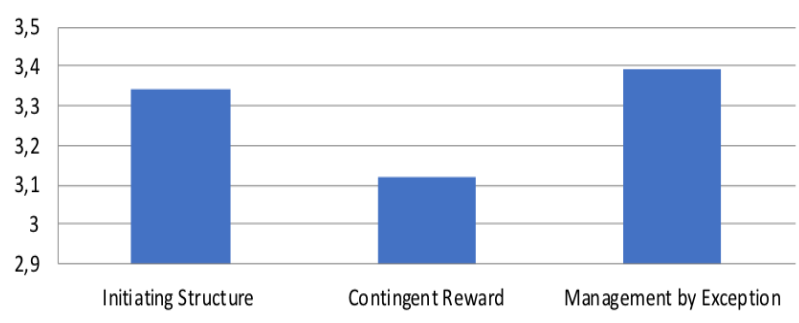

Gambar 7. Task orientation 
Orientasi paling rendah yang terdapat pada profil pemimpin publik adalah orientasi terhadap tugas. Secara lebih rinci, orientasi terhadap tugas ini dapat dilihat dalam gambar 7. Dari sisi orientasi tugas, profil pemimpin yang diharapkan pada generasi milenial lebih mengarah pada menjalankan tugas-tugas sesuai dengan ketentuan yang ada sebagai pemimpin. Pemimpin diharapkan dapat adil dalam memberikan penghargaan maupun punishment pada kinerja karyawan, dan secara terus-menerus melakukan improvement untuk memberikan pelayanan pada masyarakat. Hasil tersebut senada dengan temuan dari Alajili dan Noor (2018). Hal ini menunjukkan, secara khusus, tidak ada harapan tertentu diluar tanggung jawab umum pelaksanaan tugas sebagai pemimpin publik yang diharapkan ada pada sosok pemimpin. Dengan melakukan tugasnya sesuai dengan ketentuan sudah cukup memenuhi harapan atas profil pemimpin pada generasi milenial. Pemimpin dianggap efektif apabila mereka membantu bawahannya untuk mencapai hasil yang bernilai tinggi (Stogdill, 1974). Selain itu pemimpin yang efektif adalah yang memberi kejelasan alur (House, 1971).

Penelitian ini memberikan temuan bahwa pemimpin yang diharapkan oleh generasi milenial lebih didasarkan pada karakter personal, terutama pada aspek karismatik yang dimiliki oleh pemimpin. Faktor kedekatan dengan rakyat, fokus pada upaya peningkatan kesejahteraan rakyat, memiliki nilai yang lebih tinggi bagi generasi milenial. Adanya sejumlah prestasi juga memberikan nilai tambah pada profil pemimpin yang dipilih generasi milenial.

\section{Simpulan}

Simpulan dari penelitian ini adalah pentingnya penilaian positif terhadap profil pemimpin terutama dari sisi karisma yang dimiliki pemimpin merupakan faktor penting yang seharusnya dimiliki oleh pemimpin bagi generasi milenial. Ciri-ciri karismatik merupakan faktor penting yang perlu dimiliki oleh pemimpin. Selain itu, interaksi positif antara pemimpin dan masyarakat berupa perhatian terhadap kesejahteraan rakyat dan upaya untuk dapat memberdayakan masyarakat juga memberikan nilai yang bermanfaat dalam menambah nilai keterpercayaan pemimpin pada generasi milenial. Aspek orientasi tugas merupakan faktor terakhir dalam pemilihan sosok pemimpin yang baik bagi generasi milenial. Dengan melaksanakan tugas sesuai kewajiban yang ada, telah cukup dapat mengambil hati generasi milenial, namun dengan adanya sejumlah prestasi dan pembanding bahwa upayanya telah lebih maju atau lebih baik dari prestasi yang dimiliki sebelumnya.

\section{Daftar Pustaka}

Alajili, S. M. S., \& Noor, K. M. (2018). The integration of behaviours and social competencies of leadership and its impact on employees' citizenship behaviour among staff of commercial banks in West Libyan. Scholars Journal of Economics, Business and Management (SJEBM), 5(3), 174-183. https://doi.org/10.21276/sjebm.2018.5. 3.6

Badan Pusat Statistik. (2019). Provinsi Jawa Barat. Badan Pusat Statistik. https://jabar.bps.go.id/backend/materi_ ind/materiBrsInd-20190506111859.pdf

Burke, R. J., Cooper, C. L., \& Antoniou, A. S. G. (2015). The multi-generational and aging workforce: Challenges and opportunities. Edward Elgar Publishing. https://doi.org/10.4337/978178347658 9

Derue, D. S., Nahrgang, J. D., Wellman, N., \& Humphrey, S. E. (2011). Trait and behavioral theories of leadership: An integration and meta-analytic test of their relative validity. Personnel Psychology, 64(1), 7-52. https://doi.org/10.1111/j.1744- 
6570.2010.01201.x

Enthoven, I. (2016). The effect of different leadership styles on organizational citizenship behavior: A meta-analytic investigation (Thesis unpublished). University of Amsterdam Netherlands. http://www.scriptiesonline.uba.uva.nl/d ocument/643406

Fauziah, H. (2015). Fakor-faktor yang mempengaruhi prokrastinasi akademik pada mahasiswa fakultas psikologi UIN SGD Bandung. Psympathic: Jurnal Ilmiah Psikologi, 2(2), 123-132. https://doi.org/10.15575/psy.v2i2.453

Hammal, G. (2006). Task and relationship orientations of organizational culture in the framework of metaphorical perspective (Thesis unpublishd). Faculty of Economics and Business Administration University of Tartu.

House, R. J. (1971). A path-goal theory of leader

effectiveness. Administrative

Science Quarterly. 16, 321-328.

Jones, C., \& Hosein, A. (2010). Profiling university students' use of technology: Where is the net generation divide? International Journal of Technology, Knowledge and Society, 6(3), 43-58. https://doi.org/10.18848/18323669/CGP/v06i03/56097

Kowske, B. J., Rasch, R., \& Wiley, J. (2010). Millennials' (lack of) attitude problem: An empirical examination of generational effects on work attitudes. Journal of Business and Psychology, 25(2), 265-279. https://doi.org/10.1007/s10869-0109171-8

Morgeson, F. P., DeRue, D. S., \& Karam, E. P. (2010). Leadership in teams: A functional approach to understanding leadership structures and processes. Journal of Management, 36(1), https://doi.org/10.1177/014920630934 7376

Mujtaba, B. G., \& Isomura, K. (2012). Examining the Japanese leadership orientations and their changes.
Leadership and Organization Development Journal, 33(4), 401-420. https://doi.org/10.1108/014377312112 29322

Mujtaba, B. G., Lian, Y., Chen, L. Y., \& Yunshan, V. L. (2010). Leadership orientation of chinese professionals in the automotive industry: Comparing their task and relationship tendencies. Global Journal of Management and Business Research, 10(2).

Myers, C. G. (2014). Leadership development: A review and agenda for future research. Oxford Handbooks Online.

Northouse, P. (2013). Leadership theory and practice. Sage Publikations, Inc.

Robbins, P. S. (2002). Prinsip-prinsip perilaku organisasi, edisi kelima. Alih bahasa Halida \& Dewi Sartika. Erlangga.

Stogdill, R. M. (1974). Handbook of leadership: A survey of theory and and research. Free Press.

Simões, L., \& e Gouveia, L. (2008). Targeting the millennial generation. Jornados de Publikidade $e$ Comunicacao, 21.

Sun, Y., Gergen, E., Avila, M., \& Green, M. (2016). Leadership and job satisfaction: Implications for leaders of accountants. American Journal of Industrial and Business Management, 06(03), 268-275. https://doi.org/10.4236/ajibm.2016.630 24

Yukl, G. (2009). Kepemimpinan dalam organisasi. Alih bahasa: Budi Supriyanto. Indeks. 